\title{
Urinary 3-methylhistidine excretion in man: the role of protein-bound and soluble 3-methylhistidine
}

\author{
BY GABOR HUSZAR, GEORGE GOLENWSKY, JOHN MAIOCCO, \\ AND EDWARD DAVIS \\ Departments of Obstetrics and Gynecology and Pediatrics, Yale University School of \\ Medicine, 333 Cedar Street, PO Box 3333, New Haven, CT 06510, USA
}

\section{(Received 11 August 1982 - Accepted 11 October 1982)}

\begin{abstract}
1. The influence of dietary meat and meat stock intake on urinary excretion of 3-methylhistidine (3MH) was examined in human adults.

2. In the absence of $3 \mathrm{MH}$ ingestion for $\mathbf{4 8} \mathrm{h}$, the study subjects adjusted to an intrinsic urinary $3 \mathrm{MH}$ : creatinine value. If the meat and meat stock-free diet was maintained on subsequent days, only minute diurnal variations occurred, and the values of random urine samples during the day were representative of the $24 \mathrm{~h} 3 \mathrm{MH}$ : creatinine value.

3. The mean 3MH: creatinine value (SD) for a group of adults $(n 7)$ was $0.105 \pm 0.023(\mu \mathrm{mol}$ of $3 \mathrm{MH} / \mathrm{mg}$ creatinine), which is approximately $35 \%$ lower than the corresponding value in healthy growing infants $(0.148 \pm 0.039)$ (Seashore et al. 1981).

4. Ingestion of meat soup and meat causes different patterns of urinary excretion of $3 \mathrm{MH}$ which are consistent with the finding that meat extracts, such as soup and stock, contain considerable amounts of $3 \mathrm{MH}$. The $3 \mathrm{MH}$ contents of beef, chicken and turkey were $3.8 \pm 0.15,3.0 \pm 0.09$ and $2.3 \pm 0.29 \mu \mathrm{mol} / \mathrm{g}$ dry wt meat respectively. All three meats contained a water-soluble $3 \mathrm{MH}$-fraction (\% total $3 \mathrm{MH}$ : beef 8 , chicken 21 , turkey 23 ). Amino acid analysis of the soluble fraction with or without hydrochloric acid hydrolysis demonstrated free $3 \mathrm{MH}$ in chicken and turkey (5.2 and $2.8 \%$ of the total respectively) but not in beef.

5. Patients undergoing urinary $3 \mathrm{MH}$ measurements should maintain a diet that is free not only of solid meats, but also of meat stock. The ingestion of commercial food products (e.g. frozen or canned meals, sauces, pizza, etc.) may impair the validity of such measurements because of their meat-stock content.

6. A dietary regimen is presented which is based on a shorter $12 \mathrm{~h}$ urine collection. The shorter collection time is satisfactory in the light of the steady rate of $3 \mathrm{MH}$-excretion after $2 \mathrm{~d}$ of a diet free of meat and meat stock.
\end{abstract}

The unusual amino acid 3-methylhistidine (3MH) is present as a single residue in the peptide chains of myosin and actin (Huszar \& Elzinga, 1971; Elzinga et al. 1973). Upon breakdown of these muscle proteins, $3 \mathrm{MH}$ is not re-utilized, but is rapidly and quantitatively excreted in the urine (Young et al. 1973; Long et al. 1975). It is increasingly apparent that the measurements of urinary $3 \mathrm{MH}$ excretion and of the ratio of urinary $3 \mathrm{MH}$ :creatinine (cr), which is proportional to the muscle mass (Graystone, 1968), are valuable in the assessment of protein catabolism, although the relative contributions of $3 \mathrm{MH}$ from actin and myosin in different tissues are under investigation (Millward et al. 1980; Harris, 1981). The 3MH:cr value has already been successfully validated in various animal and human studies (e.g. Wannemacher et al. 1975; Gross et al. 1978; Young \& Munro, 1978; Griggs et al. 1980; Elia et al. 1981 ; Long, Birkhahn, Geiger, Betts et al. 1981 ; Seashore et al. 1981). Controversy persists, however, with respect to basal or normal values for urinary $3 \mathrm{MH}$ excretion and $3 \mathrm{MH}: \mathrm{cr}$ values in human subjects (reviewed in part by Lukaski et al. 1981). We believe that most of the inconsistent values are due to the vague definition of the meat-free or flesh-free diet ingested by the study participants during the experiments. Although interference with $3 \mathrm{MH}: \mathrm{cr}$ measurements as a result of ingestion of meat has been detected by several authors (Tomas et al. 1979; Griggs et al. 1980; Long, Birkhahn, Geiger, Betts et al. 1981; Lukaski et al. 1981), the quantitative implications of small diet errors or inadvertent ingestion of meat-free foods which actually contain meat stock have not been recognized. 
In examining this question, we found that (1) wide fluctuations in urinary $3 \mathrm{MH}$ :cr values occur during the day in patients on their regular diets; (2) a period of at least $2 \mathrm{~d}$ abstinence from meat and meat stock is necessary before dietary $3 \mathrm{MH}$ clears and subjects attain a basal level of $3 \mathrm{MH}$ excretion; (3) after meat ingestion $3 \mathrm{MH}$ quickly appears in the urine, which indicates that some of this amino acid is present in a soluble protein-bound fraction of meats. This observation has been confirmed by measurement of meat extracts and of urinary $3 \mathrm{MH}$ excretion in experimental subjects; (4) various meat-free or flesh-free foods may actually contain substantial amounts of $3 \mathrm{MH}$ from the added meat stock; and (5) patients who participate in $3 \mathrm{MH}$ excretion studies should ingest well-defined diets. We have devised a meat-free, protein-substituted diet that satisfies both the protein and energy requirements of patients.

\section{EXPERIMENTAL DESIGN AND METHODS}

$3 M H: c r$ values in fractional urines. Adults on their normal diet were asked to collect $24 \mathrm{~h}$ urine samples and to save approximately $2 \mathrm{ml}$ urine from three to four voids during the day.

Expt 1 . The 8 d experiment was carried out as follows. Healthy adult subjects were studied (three females, four males, with weights (mean $\pm \mathrm{SD}$ ) $54 \pm 5$ and $81 \pm 5 \mathrm{~kg}$, respectively) age between 25 and 60 years. Subjects ingested a meat-free, protein-substituted diet until 18.00 hours on the fourth experimental day, when six of the seven ate roast beef and roast turkey until satisfied. Subject D (see Table 1, p. 290) ate cold-cuts. On days 5-8, the subjects resumed their usual diets. Urine specimens $(24 \mathrm{~h})$ were collected for $8 \mathrm{~d}$. Two of the seven subjects also collected fractional urines (1-2 ml) on days $3,4,5$ and 6 . All urine samples were stored at $-20^{\circ}$.

Expt 2. Soup-meat experiment. The experiment was carried out in two men (ages 40 and 25 years, weights 84 and $75 \mathrm{~kg}$ ). The subjects remained on the meat-free, protein-substituted diet for $11 \mathrm{~d}$, except for ingesting soup in the late evening of day 5 and meat in the evening of day 8. Soup and meat were prepared as follows. Lean beef $(1.68$ and $1.5 \mathrm{~kg}$ or $2 \%$ of participant's body-weight) was sliced to a thickness of approximately $10 \mathrm{~mm}$, and two consommes were cooked in $3 \mathrm{vol}$. of water overnight with vegetables and spices. The soups were concentrated by boiling, then refrigerated, with the meat, until consumption. Daily $24 \mathrm{~h}$ urine collections were carried out for eleven study days; urine samples were stored at $-20^{\circ}$.

Determination of soluble and protein-bound $3 \mathrm{MH}$ in meat. Chicken breast, turkey breast and round roast of beef were used. Six independent determinations in each source were carried out as follows: $(a)$ aliquots of the meat were hydrolysed in $6 \mathrm{M}$-hydrochloric acid and total $3 \mathrm{MH}$ per $\mathrm{g}$ muscle weight was determined; $(b)$ further samples of the meats were chopped and cooked ( 3 vol of water at $90^{\circ}$ for three periods of $6 \mathrm{~h}$ ). The suspensions were centrifuged; pooled, dried and hydrolysed in $6 \mathrm{M}-\mathrm{HCl}$. The meat pellets were also hydrolysed in $6 \mathrm{M}-\mathrm{HCl}$. Both the soup and meat samples had been subjected to $3 \mathrm{MH}$ determinations. Thus, total $3 \mathrm{MH}$ as well as soluble and insoluble $3 \mathrm{MH}$ were determined for all three meats. Samples of the soluble fractions were also applied to the amino acid analyser without acid hydrolysis to determine free $v$. peptide-bound $3 \mathrm{MH}$. Dry weights of the meats were determined after lyophilization $(48 \mathrm{~h})$.

$3 M H$ content of foods. Samples of pizza sauces, various soups and gravies and sauces of baked beans were hydrolysed in $6 \mathrm{M}-\mathrm{HCl}$ and subjected to $3 \mathrm{MH}$ determination.

Amino acid analysis. Urine and food samples were hydrolysed in $6 \mathrm{M}-\mathrm{HCl}$ acid after evacuation at $100^{\circ}$ for $18 \mathrm{~h}$. Each sample was dried and dissolved in $0.2 \mathrm{M}$-citrate buffer, pH 2.2, filtered, and applied to a Beckman 119 automated amino acid analyser. The elution 
programme for the basic and methylated amino acids was developed as previously published (Huszar \& Elzinga, 1971). Recovery of $3 \mathrm{MH}$ ( $>95 \%$ ) was monitored throughout the study.

Creatinine determinations. Jaffe's (1886) procedure was used. Urine (1 ml) was mixed with $8 \mathrm{ml}$ picric acid $(1 \mathrm{~g} / 1)$ and $0.06 \mathrm{ml}$ sodium hydroxide $(100 \mathrm{~g} / \mathrm{l})$. After colour development for $15 \mathrm{~min}$, absorbance was determined at $520 \mathrm{~mm}$ and compared to a standard curve.

\section{RESULTS}

\section{$3 M H:$ cr values in fractional urines}

In preliminary experiments, $3 \mathrm{MH}$ :cr ratios were measured in urine samples of experimental subjects consuming their regular diet throughout the day and in $24 \mathrm{~h}$ urine collections from the same day. Ratios varied by as much as $200 \%$ among the samples of spot urines and the $24 \mathrm{~h}$ urine collections (e.g. $0 \cdot 280,0 \cdot 542,0.260$ in the fractional urines $v .0 .408$ for $24 \mathrm{~h}$ collections; $0.264,0.318,0.410$ in the fractional urines $v .0 .352$ for $24 \mathrm{~h}$ collections; 0.146 , $0 \cdot 180,0 \cdot 340$ in the fractional urines $v .0 \cdot 210$ for $24 \mathrm{~h}$ collections).

\section{Expt 1. Influence of meat ingestion on $3 M H: c r$ value}

The $8 \mathrm{~d}$ experiment included $3 \mathrm{~d}$ of a meat-free diet, $1 \mathrm{~d}$ of a meat load, and $4 \mathrm{~d}$ of a regular diet.

(a) $3 M H$ : cr values showed a well-defined pattern (Table 1). In the absence of meat intake, ratios declined in the first $3 \mathrm{~d}$ until they reached (mean \pm SD) $0 \cdot 105 \pm 0 \cdot 023$. After meat ingestion on days 4 and 5 , the mean $3 \mathrm{MH}: \mathrm{cr}$ value increased by three times the basal value. If the meat-free diet was maintained for several days, only minute variations occurred in the daily $3 \mathrm{MH}$ :cr value of a particular individual. The importance of a meat-free diet is well demonstrated in terms of the extent of elevation of $3 \mathrm{MH}$ :cr following meat ingestion on day 4. The individual differences in the increases were due to variations in the amounts and in the preparation of the poultry and beef ingested. On days 1, 6, 7 and 8, reflecting the subjects' ad lib. diet, the mean $3 \mathrm{MH}$ :cr values were similar.

(b) Daily $3 \mathrm{MH}$ and creatinine excretion (Table 2) values follow the pattern of $3 \mathrm{MH}: \mathrm{cr}$ values. $3 \mathrm{MH}$ excretion declined in the first $3 \mathrm{~d}$ of the experiment and increased after meat ingestion on the 4th and 5th days. The mean ( \pm SD) $3 \mathrm{MH}$ excreted on day 3 by this study group was $138 \pm 51 \mu \mathrm{mol} / 24 \mathrm{~h}$. When the subjects' weights were considered, mean ( $\pm \mathrm{SD}$ ) $3 \mathrm{MH}$ excretion was $1.95 \pm 0.44 \mu \mathrm{mol}(2.15$ for men, 1.68 for women $) / \mathrm{kg}$ body-weight per $24 \mathrm{~h}$. The latter value was similar to those reported by Young et al. (1973), Gross et al. (1978), Griggs et al. (1980) and Winterer et al. (1980).

Creatinine excretion during the $8 \mathrm{~d}$ period did not change considerably (Table 2 ). The excretions were somewhat lower on day 3 , and somewhat higher on days 6 and 7 , than the $8 \mathrm{~d}$ mean value. The slight increase in $\mathrm{cr}$ excretion due to meat ingestion was delayed compared to the $3 \mathrm{MH}$ excretion. The mean cr excretion for the group was $22 \mathrm{mg} / \mathrm{kg}$ body-weight per $24 \mathrm{~h}$, which corresponds well with values published by other investigators (McKeran et al. 1978; Long, Birkhahn, Geiger, Betts et al. 1981).

\section{Expt 2. The soup-meat experiment}

The rapid rise in $3 \mathrm{MH}: \mathrm{cr}$ values after the meat meal suggested that meats contain a soluble pool of $3 \mathrm{MH}$ that is quickly absorbed and appears in the urine before the digestion of muscle proteins. Thus, Expt 2, consisting of four meat-free days, one soup day, two meat-free days, one meat day and three meat-free days, was performed with daily $3 \mathrm{MH}$ and $\mathrm{cr}$ measurements throughout. The $3 \mathrm{MH}: \mathrm{cr}$ values were initially high and stabilized at the basal level by day 3 (Table 3). After the consumption of soup on day 5, 3MH:cr values and $3 \mathrm{MH}$ excretion increased on day 6 and declined on days 7 and 8 . After the ingestion 


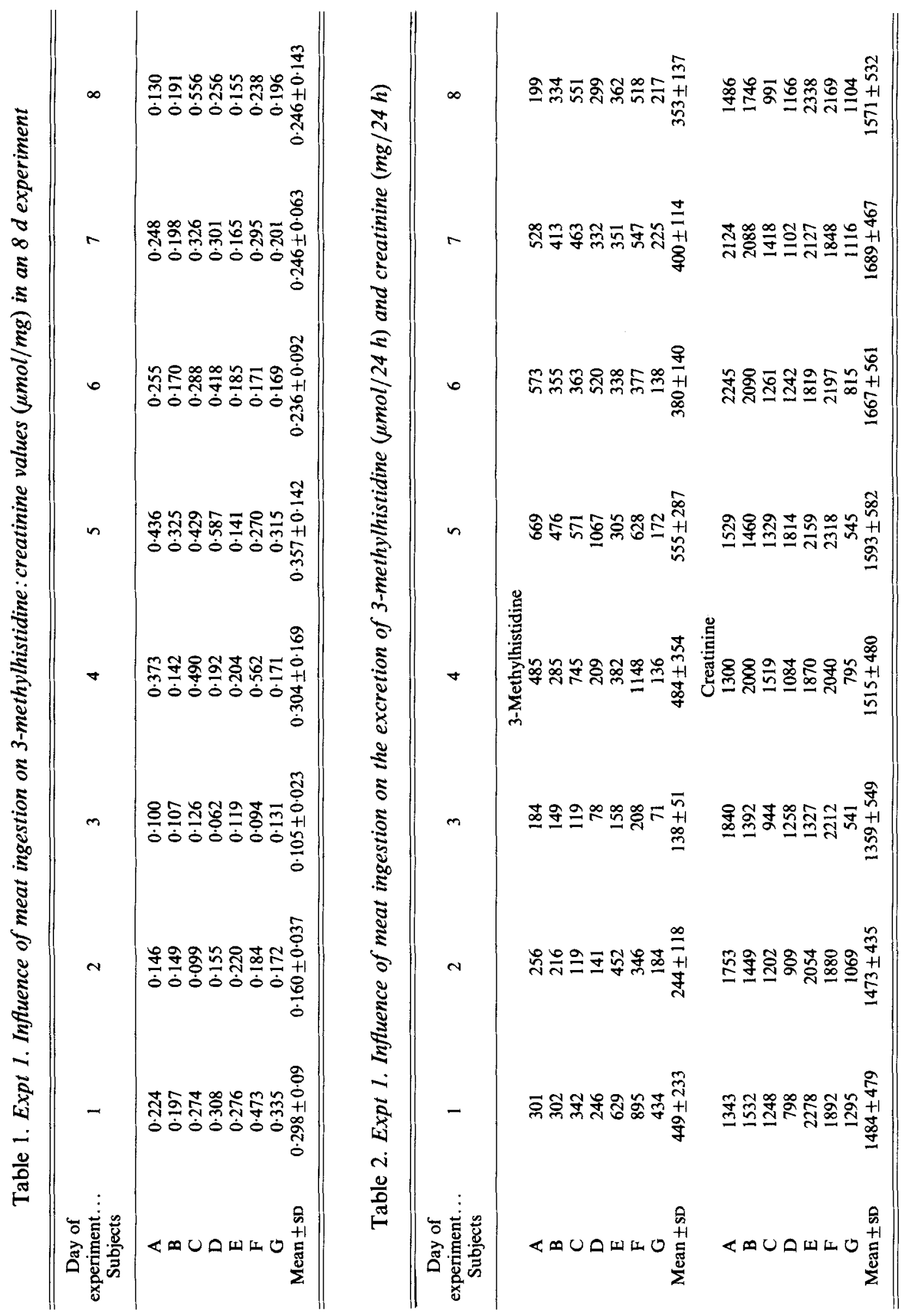


Table 3. Expt 2. Influence of soup-meat ingestion on urinary creatinine (cr) and 3-methylhistidine $(3 \mathrm{MH})$ in an $11 \mathrm{~d}$ experiment

(Subjects consumed a meat-free protein-substituted diet for $11 \mathrm{~d}$ except for ingesting soup on day 5 and meat on day 8 )

\begin{tabular}{cccccc}
\hline \hline Subject & $\begin{array}{c}\text { Day of } \\
\text { experiment }\end{array}$ & $\begin{array}{c}\text { Volume } \\
(\mathrm{ml})\end{array}$ & $\begin{array}{c}\mathrm{cr} \\
(\mathrm{mg})\end{array}$ & $\begin{array}{c}3 \mathrm{MH} \\
(\mu \mathrm{mol})\end{array}$ & $\begin{array}{c}3 \mathrm{MH}: \mathrm{cr} \text { value } \\
(\mu \mathrm{mol} / \mathrm{mg})\end{array}$ \\
\hline $\mathrm{A}$ & 1 & 1300 & 1860 & 822 & $0 \cdot 442$ \\
& 2 & 1100 & 1650 & 346 & $0 \cdot 210$ \\
& 3 & 630 & 1525 & 208 & $0 \cdot 136$ \\
& 4 & 990 & 1614 & 221 & $0 \cdot 137$ \\
& 5 & 1050 & 1796 & 232 & $0 \cdot 129$ \\
& 6 & 810 & 1725 & 327 & $\mathbf{0} \cdot 190$ \\
& 7 & 970 & 1552 & 198 & $0 \cdot 128$ \\
& 8 & 1440 & 1613 & 162 & $0 \cdot 101$ \\
& 9 & 1270 & 1740 & 398 & $\mathbf{0} \cdot 229$ \\
& 10 & 1200 & 1642 & 241 & $\mathbf{0} \cdot 146$ \\
& 11 & 1010 & 1626 & 199 & $0 \cdot 123$ \\
& 1 & 1000 & 1360 & 496 & $0 \cdot 365$ \\
& 2 & 1950 & 1482 & 303 & $0 \cdot 205$ \\
& 3 & 660 & 1129 & 154 & $0 \cdot 137$ \\
& 4 & 830 & 1429 & 211 & $0 \cdot 128$ \\
& 5 & 1000 & 1700 & 207 & $0 \cdot 122$ \\
& 6 & 1650 & 1914 & 371 & $\mathbf{0} \cdot 194$ \\
& 7 & 1318 & 1843 & 221 & $0 \cdot 120$ \\
& 8 & 1130 & 1684 & 188 & $0 \cdot 112$ \\
& 9 & 1080 & 1750 & 420 & $\mathbf{0} \cdot 240$ \\
& 10 & 1010 & 1576 & 277 & $\mathbf{0 . 1 7 6}$ \\
& 11 & 880 & 1560 & 198 & $0 \cdot 127$ \\
\hline \hline
\end{tabular}

of meat on day $8,3 \mathrm{MH}$ excretion increased on days 9 and 10 . Both $3 \mathrm{MH}: \mathrm{cr}$ and $3 \mathrm{MH}$ excretion declined to basal levels by day 11, the 3rd day after meat consumption.

As soup and meat for each subject had been prepared from meat weighing $2 \%$ of his body-weight, the changes in $3 \mathrm{MH}$ :cr values may be comparable. Values for $3 \mathrm{MH}: \mathrm{cr}$ on day 6 were $0 \cdot 190$ v. $0 \cdot 194$, and on day 9 were $0 \cdot 229$ v. $0 \cdot 240$ in the two subjects. For days $3,4,5$ and 11 , each of which followed the $48 \mathrm{~h}$ meat-free period, the mean $3 \mathrm{MH}$ : cr value was $0 \cdot 129$. After soup ingestion, $3 \mathrm{MH}: \mathrm{cr}$ values increased for $1 \mathrm{~d}$, while they increased for $2 \mathrm{~d}$ after meat ingestion. In further experiments we determined whether the rapidly-rising soluble $3 \mathrm{MH}$ was present in the urine as free $3 \mathrm{MH}$ or as $3 \mathrm{MH}$-containing peptides.

\section{$3 M H$ content of various meats}

$3 \mathrm{MH}$ content was measured on $\mathrm{HCl}$-hydrolysed samples in turkey breast, chicken breast and beef round. The $3 \mathrm{MH}$ concentrations varied by species: $3.8 \pm 0.15,3.0 \pm 0.09$ and $2 \cdot 3 \pm 0.29 \mu \mathrm{mol} 3 \mathrm{MH} / \mathrm{g}$ per dry weight in turkey, chicken and beef respectively. The distribution of water-soluble $v$. protein-bound $3 \mathrm{MH}$ was also different in the three meats. The soluble (in the cooking liquid) $v$. meat-bound $3 \mathrm{MH}$ (expressed as \% of the total) was beef $8-92$, chicken 21-79, turkey 23-77. The poultry meats contained much higher percentages of soluble $3 \mathrm{MH}$. Amino acid analysis of the soluble fraction with or without $\mathrm{HCl}$ hydrolysis gave the amount of $3 \mathrm{MH}$ present as free $3 \mathrm{MH} v$. peptide-bound $3 \mathrm{MH}$, either in small digestion products of actin or myosin or in the $3 \mathrm{MH}$-containing dipeptide, balenine (Harris \& Milne, 1980). In chicken, $25 \%$ of soluble $3 \mathrm{MH}$ was free $3 \mathrm{MH}(5 \cdot 2 \%$ of the total in muscle), in turkey the value was $12 \%(2.8 \%$ of total $3 \mathrm{MH})$, whereas in beef none of the $8 \%$ soluble $3 \mathrm{MH}$ appeared as free $3 \mathrm{MH}$ before $\mathrm{HCl}$ hydrolysis. 
Table 4. 3-Methylhistidine $(3 \mathrm{MH})$ collection and diet outline for metabolic studies influencing $3 \mathrm{MH}$ measurements

This is a meat-free, protein-substituted diet. The experimental period is $3 \mathrm{~d}$.

Please observe the following schedule:

Night before

$\begin{array}{ll}\text { Day 1 } & \\ \text { Day 2 } & \left.\begin{array}{l}\text { Breakfast } \\ \text { Lunch } \\ \text { Dinner } \\ \text { Breakfast } \\ \text { Lunch } \\ \text { Dinner } \\ \text { Day 3 }\end{array}\right\} \\ \text { Breakfast } \\ \text { Lunch } \\ \text { Dinner }\end{array}$

You may eat moderate amounts of meat

No meat

No meat

No meat

Have dinner after 18.00 hours. Before dinner void one more time. Stop collecting and you may resume your regular diet.

You should ingest approximately $80 \mathrm{~g}$ protein/d. The following amounts of non-meat foods represent one-fourth of your daily protein: three eggs, $85 \mathrm{~g}$ cheese, 0.851 milk (three cups), $170 \mathrm{~g}$ cottage cheese, 6 tablespoons peanut butter. Any combination of four portions is satisfactory. For example:

(a) Three eggs, $0 \cdot 851$ milk, $170 \mathrm{~g}$ cottage cheese, $85 \mathrm{~g}$ cheese.

(b) Six eggs, 6 tablespoons peanut butter, 0.851 milk.

(c) 1.71 milk, three eggs, $170 \mathrm{~g}$ cottage cheese.

(d) $340 \mathrm{~g}$ cottage cheese, six eggs.

Feel free to select vegetables, fruits, breads, cereal, pastry, and other non-meat products as desired. Please do not eat prepared soups, frozen meals, pizza or processed food of any kind, as they may contain meat juices.

\section{$3 M H$ content of meat-free foods and diet protocol for $3 M H: c r$ measurements}

In the course of our metabolic studies, and in reviewing results from other laboratories, we found that subjects on meat-free or flesh-free diets sometimes showed unexpectedly high urinary $3 \mathrm{MH}: \mathrm{cr}$ values. In investigating the $3 \mathrm{MH}$ content of the foods ingested by our study subjects, we found that a number of the supposedly meat-free processed foods (e.g. baked beans, cheese pizza, vegetable soup, mushroom gravy) contained considerable amounts of $3 \mathrm{MH}$ from the added meat stock. Some examples (expressed as nmol $3 \mathrm{MH} / 100 \mathrm{~g}$ food) include brown sauce, 416 , mushroom gravy 1120 , won ton soup 340, chunky vegetable soup 672 , baked beans 516 , pizza and spaghetti sauces $300-700$, consomme (home-made) 2200 . To eliminate this problem with self-selected meat-free diets, we designed a protein-substituted, meat and meat stock-free diet that our experimental subjects (Huszar \& Golenwsky, 1978; Huszar et al. 1982) used successfully (Table 4).

\section{DISCUSSION}

Since $3 \mathrm{MH}$ has been recognized as a unique marker of protein catabolism, the $24 \mathrm{~h} 3 \mathrm{MH}$ measurement has been utilized in a number of clinical studies of hospitalized or outpatient subjects (for example, see Wannemacher et al. 1975; Gross et al. 1978; Young \& Munro, 1978; Griggs et al. 1980; Long, Birkhahn, Geiger \& Blakemore, 1981; Elia et al. 1981; Seashore et al. 1981). Certain patients were given either a meat-free diet or specified amounts of dietary meat, whereas others received intravenous alimentation. The influence of dietary meat intake on urinary $3 \mathrm{MH}$ excretion was not considered in some of the studies. An early report (Block et al. 1965) failed to find a close relationship between these two factors. We have measured urinary $3 \mathrm{MH}: \mathrm{cr}$ values in evaluating the metabolic state of infants (Seashore et al. 1981) and of diabetic (Huszar et al. 1982) and obstetrical patients (Huszar \& Golenwsky, 1978). The infants (ingesting formula or mother's milk) 
presented no problems with respect to diet, but with the adult outpatients, it has been difficult at times to obtain reliable serial measurements. In some cases, we found unexplained high $3 \mathrm{MH}: \mathrm{cr}$ values, even though we were certain that the subjects abstained from meat.

The relationship between dietary meat intake and variability in urinary $3 \mathrm{MH}$ excretion and $3 \mathrm{MH}: \mathrm{cr}$ values was demonstrated in the fractional urine samples and in the $8 \mathrm{~d}$ experiment in the present study. During the first $2 \mathrm{~d}$ of the meat-free diet, the $3 \mathrm{MH}$ : $\mathrm{cr}$ values of the seven subjects decreased to the basal level. The amounts of meat ingested before commencement of the meat-free diet did not influence the $48 \mathrm{~h}$ period necessary to reach endogenous 3MH excretion. For instance, the $3 \mathrm{MH}: \mathrm{cr}$ value for subject $\mathrm{F}$ declined from 0.473 to 0.094 . We found, in similar studies, that if the meat-free diet was maintained for several days longer, only minute variations occurred in the daily $3 \mathrm{MH}: \mathrm{cr}$ values. In the absence of meat or meat-stock ingestion, the variations in $3 \mathrm{MH}: \mathrm{cr}$ value also diminished, and the ratios in fractional urines during the day became true reflexions of the $24 \mathrm{~h}$ value.

The mean basal $( \pm \mathrm{SD}) 3 \mathrm{MH}$ :cr value for the experimental group was $0.105 \pm 0.023 \mu \mathrm{mol}$ $3 \mathrm{MH} / \mathrm{mg} \mathrm{cr}$. This value of approximately $0 \cdot 110$ was confirmed in our other studies (Huszar et al. 1982) and was approximately $35 \%$ lower than the corresponding value for healthy, growing, premature infants $(0 \cdot 148 \pm 0.039$; Seashore et al. 1981). We believe that this phenomenon is related to the higher rate of protein turnover in growing infants. As found by other investigators, there were also sex-related differences in $3 \mathrm{MH}$-excretion when expressed as $\mu \mathrm{mol} / 3 \mathrm{MH}$ per $\mathrm{kg}$ body-weight per day ( 2.15 for men, 1.68 for women). In light of these developmental and sex-related differences, as well as the age-related changes reported by others (Bilmazes et al. 1978; Tomas et al. 1979), we have used control subjects matched for age and sex in our recent studies.

Another notable observation was the sudden rise in $3 \mathrm{MH}$ excretion shortly after meat ingestion. Measurements of spot urine samples indicated a two- to threefold increase in $3 \mathrm{MH}: \mathrm{cr}$ value in urine samples after the ingestion of meat on the evening of the 4th day of the $8 \mathrm{~d}$ experiment. This rapid rise, which is not consistent with proteolytic digestion of actin and myosin, indicated the presence of a soluble $3 \mathrm{MH}$ fraction in the meat. Soluble $3 \mathrm{MH}$ is presumably absorbed and excreted quickly, whereas protein-bound $3 \mathrm{MH}$ appears in the urine only after the meat has been digested.

The existence of soluble and protein-bound $3 \mathrm{MH}$ was demonstrated by the excretion patterns of the soup-meat experiment. On day 5, after the ingestion of soup, the $3 \mathrm{MH}$ excretion rose briefly in the two subjects: from 203 and $197 \mu \mathrm{mol} / 24 \mathrm{~h}$ (the average of days $3,4,5,7,8$ and 11 ) to 327 and $371 \mu \mathrm{mol} / 24 \mathrm{~h}$ respectively. After meat ingestion on day 8 the ratios were higher: $398-420$ and $241-277 \mu \mathrm{mol} / 24 \mathrm{~h}$ on days 9 and 10 respectively. These findings demonstrate that cooked-meat products lose part of their $3 \mathrm{MH}$ content to the cooking liquid; hence meat stock contains $3 \mathrm{MH}$.

The $3 \mathrm{MH}$ content of meats, as well as the distribution of soluble $v$. protein-bound $3 \mathrm{MH}$, differs in the various species. The $3 \mathrm{MH}$ content of chicken $(3.0 \mu \mathrm{mol} / \mathrm{g}$ dry weight) corresponds well with recent values (Hillgartner et al. 1981). The soluble $3 \mathrm{MH}$ fraction is approximately three times higher in poultry than in beef $(22 \mathrm{v} .8 \%)$. Free $3 \mathrm{MH}$ is not present in beef. The free $3 \mathrm{MH}$ content of chicken is higher than that of turkey $(5 \cdot 2 v .2 \cdot 8 \%)$. Free $3 \mathrm{MH}$ represents catabolic products, as simple amino acids are not substrates for methylating enzymes (Young et al. 1972; Hillgartner et al. 1981). The 3MH liberated by $\mathrm{HCl}$ hydrolysis orginates in soluble peptides that are either digestion products of actin and myosin or of the $\beta$-alanine-3MH dipeptide, balenine. The balenine contents of various meats have been recently reported (Harris \& Milne, 1980, 1981).

Several meat-free food products enriched with meat-stock (primarily from chicken) contained $3 \mathrm{MH}$, due to the soluble $3 \mathrm{MH}$ fraction. Although this $3 \mathrm{MH}$ may not be a major component in some foods (e.g. baked beans, won ton soup), others (e.g. consomme or pizza 
sauces) may contain substantial amounts of $3 \mathrm{MH}$ and thus interfere with the validity of the meat-free diets. Also, the variability of the stock content of various products (e.g. pizza sauce) makes the urine collections unpredictable. It was reassuring to know, however, that none of the three commercial vegetarian food products contained $3 \mathrm{MH}$.

Our meat-free, protein-substituted dietary regimen is useful, although the participants are limited in the self-selection of foods. The $60 \mathrm{~h}$ programme includes a $48 \mathrm{~h}$ meat-free period and a $12 \mathrm{~h}$ urine collection for the measurements. The regimen is well-defined, and the protein content is adjustable for special needs (e.g. diabetes or pregnancy). The shorter urine collection increases compliance. The validity of the $3 \mathrm{MH}$ : cr ratio is assured by the $48 \mathrm{~h}$ meat-free period and the programme allows the subjects to consume meat for dinner on the third experimental day.

This research has been supported by the NICHD (Grant HD-12183).

\section{REFERENCES}

Bilmazes, C., Uauy, R., Haverberg, L. N., Munro, H. N. \& Young, V. R. (1978). Metabolism 27, 525.

Block, W. D., Hubbard, R. W. \& Steele, B. F. (1965). Nutrition 85, 419.

Elia, M., Carter, A., Bacon, S., Winearls, C. G. \& Smith, R. (1981). Br. med. J. 282, 351.

Elzinga, M., Collins, J. H., Kuehl, W. M. \& Adelstein, R. S. (1973). Proc. natn Acad. Sci., USA 70, 2687.

Graystone, J. E. (1968). In Human Growth, p. 182 [D. B. Cheek, editor]. Philadelphia: Lea \& Febiger.

Griggs, R. C., Moxley, R. T. III \& Forbes, G. B. (1980). Neurology 30, 1262.

Gross, I., Holbrook, I. B. \& Irving, M. H. (1978). Br. J. Surg. 65, 663.

Harris, C. I. (1981). Biochem. J. 194, 1011.

Harris, C. I. \& Milne, G. (1980). Biochem. Soc. Trans. 8, 552.

Harris, C. I. \& Milne, G. (1981). Br. J. Nutr. 45, 423.

Hillgartner, F. B., Williams, A. S., Flanders, J. A., Morin, D. \& Hansen, R. J. (1981). Biochemistry $196,591$.

Huszar, G. (1972). Nature, New Biol. 240, 260.

Huszar, G. \& Elzinga, M. (1971). Biochemistry, 10, 229.

Huszar, G. \& Golenwsky, G. (1978). A. Mtg Soc. Gynec. Invest. Abstr. 25.

Huszar, G., Koivisto, V., Davis, E. M. \& Felig, P. (1982). Metabolism 31, 188.

Jaffe, M. (1886). Zeitschr Physiol. Chem. 10, 391.

Long, C. L., Birkhahn, R. H., Geiger, J. W., Betts, J. E., Schiller, W. R. \& Blakemore, W. S. (1981). Metabolism 30, 756 .

Long, C. L., Birkhahn, R. H., Geiger, J. W. \& Blakemore, W. S. (1981). Am. J. clin. Nutr. 34, 1087.

Long, C. L., Haverberg, L. N., Young, V. R., Kinney, J. M. \& Munro, H. N. (1975). Metabolism $24,929$.

Lukaski, H. C., Mendez, J., Buskirk, E. R. \& Cohn, S. H. (1981). J. Am. Physiol. 302.

McKeran, R. O., Halliday, D. \& Purkiss, P. (1978). Clin. Sci. Mol. Med. 54, 471.

Millward, D. J., Bates, P. C., Grimble, G. K. \& Brown, J. G. (1980). Biochem. J. 190, 225.

Seashore, J. H., Huszar, G. \& Davis, E. M. (1981). Metabolism 30, 959.

Tomas, F. M., Ballard, F. J. \& Pope, L. M. (1979). Clin. Sci. 56, 341.

Wannemacher, R. W. Jr, Dinterman, R. E., Pekarek, R. S., Bartellom, P. J. \& Beisel, W. R. (1975). Am. J. clin. Nutr. 28, 110.

Winterer, J. Bistrian, B. R., Bilmazes, C., Blackburn, G. L. \& Young, V. R. (1980. Metabolism $29,575$.

Young, V. R., Alexis, S. D., Baliga, B. S., Munro, H. N. \& Muecke, W. (1972). J. biol. Chem. $217,3592$.

Young, V. R., Haverberg, L. N., Bilmazes, C. \& Munro, H. N. (1973). Metabolism 22, 1429.

Young, V. R. \& Munro, H. N. (1978). Fedn Proc. Fedn Am. Socs exp. Biol. 37, 2291. 